\title{
New insights on the occurrence of peperites and sedimentary deposits within the silicic volcanic sequences of the Paraná Magmatic Province, Brazil
}

\author{
A. C. F. Luchetti ${ }^{1}$, A. J. R. Nardy ${ }^{1}$, F. B. Machado ${ }^{2}$, J. E. O. Madeira ${ }^{3}$, and J. M. Arnosio ${ }^{4}$ \\ ${ }^{1}$ Instituto de Geociências e Ciências Exatas, Universidade Estadual Paulista, Rio Claro, SP, 13506-900, Brazil \\ ${ }^{2}$ Departamento de Ciências Exatas e da Terra, Universidade Federal de São Paulo, São Paulo, SP, 09920-540, Brazil \\ ${ }^{3}$ Departamento de Geologia da Faculdade de Ciências (GeoFCUL), Instituto Dom Luiz, Universidade de Lisboa, Lisboa, \\ Portugal \\ ${ }^{4}$ Instituto Geonorte, Facultad de Ciencias Naturales, Universidad Nacional de Salta, Salta, Argentina \\ Correspondence to: A. C. F. Luchetti (caroluch@rc.unesp.br)
}

Received: 14 November 2013 - Published in Solid Earth Discuss.: 16 December 2013

Revised: 29 January 2014 - Accepted: 29 January 2014 - Published: 10 March 2014

\begin{abstract}
The PMP (Paraná Magmatic Province) is characterized by lava flows of the Early Cretaceous Serra Geral Formation which covers about $75 \%$ of the Paraná Basin (southern and southeastern Brazil), composed of a thick (up to $1600 \mathrm{~m}$ ) volcanic sequence formed by a succession of petrographically and geochemically distinct units of basic and silicic composition. The whole package must have been emplaced during approximately 3 million years of nearly uninterrupted activity. A few aeolian sandstone layers, indicating arid environmental conditions (the Botucatu Formation), are interlayered in the lower basalts. Above the basalts, the Palmas and Chapecó Members are composed of silicic volcanic rocks (quartz latites, dacites, rhyodacites and rhyolites) and basalts. This paper presents new evidence of sedimentation episodes separating silicic volcanic events, expressed by the occurrence of sedimentary deposits. Interaction between the volcanic bodies and the coeval unconsolidated sediments formed peperites. The sediments were observed between basaltic lava flows and silicic rocks or interlayered in the Palmas-type rocks, between the Chapecó-type rocks and overlying basaltic flows, between silicic bodies of the Palmas and Chapecó types, and interlayered within Palmas-type units. The observed structures indicate that the sediments were still wet and unconsolidated, or weakly consolidated, at the time of volcanism, which, coupled with the sediment features, reflect environmental conditions that are different from those characterizing the Botucatu arid conditions.
\end{abstract}

\section{Introduction}

The Early Cretaceous Serra Geral Formation is the result of a major volcanic phase that covered about $917000 \mathrm{~km}^{2}$, about $60 \%$ of the surface of the Paraná Basin (Frank et al., 2009; Fig. 1). Three main petrographic types can be distinguished from macroscopic observation of these rocks. The most common type are basalts, presenting predominant intergranular texture and its variations, including subophitic, intersertal and hialophitic. The other two types of silicic rocks present massive and aphyric textures (Palmas type - ATP) and porphyritic textures (Chapecó type - ATC).

Macroscopic characteristics allowed easy separation in the field of these two members of the Serra Geral Formation and their geological mapping (Bellieni et al., 1983; Piccirillo et al., 1988). The Palmas and Chapecó rock types occur in association with basaltic flows that are more common near the top and bottom of these two lithostratigraphic units. Geological mapping also shows that the Palmas and Chapecó Members cover $63000 \mathrm{~km}^{2}$, in the states of Paraná, Santa Catarina and Rio Grande do Sul. The volume of the two members amounts to approximately $14500 \mathrm{~km}^{3}$, which corresponds to $2.5 \%$ of the total volume of the Serra Geral Formation (Nardy et al., 2002, 2008). Geochronological dating by ${ }^{40} \mathrm{Ar} /{ }^{39} \mathrm{Ar}$ shows that the age of volcanic rocks of the Serra Geral Formation ranges from 133.6 to $131.5 \mathrm{Ma}$ in its northern sector, and from 134.6 to $134.1 \mathrm{Ma}$ in the southern (Renne et al., 1992, 1996a, b; Turner et al., 1994; Ernest et al., 1999, 2002;

Published by Copernicus Publications on behalf of the European Geosciences Union. 


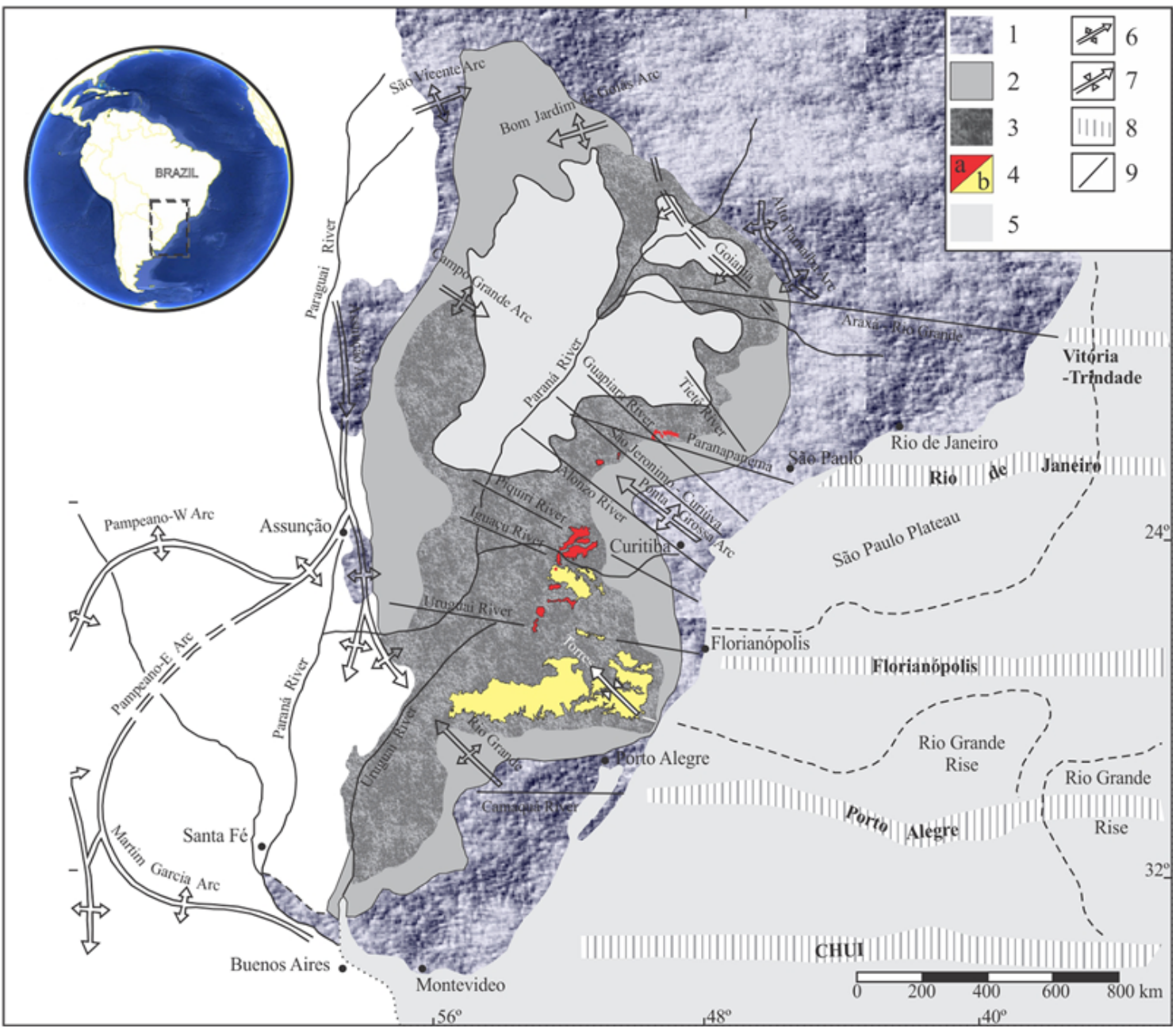

Fig. 1. Map of the Paraná Basin with the location of the acidic members of the Serra Geral Formation according to Nardy et al. (2008). Legend: 1 - pre-volcanic sedimentary rocks; 2 - basalts (the Serra Geral Formation); 3- silicic (a) Chapecó and (b) Palmas members (the Serra Geral Formation); 4 - sedimentary post-volcanic sequences (Bauru Basin); 5 - anticline structures; 6 - syncline structures; 7 - oceanic lineaments; 8 - continental lineaments.

Mincato et al., 2003; Thiede and Vasconcelos, 2010; Pinto et al., 2010). More recently, Janasi et al. (2011), using U/Pb ratios from baddeleyite/zircon crystals determined by isotope dilution thermal ionization mass spectrometry from rocks of the Chapecó Member, obtained an age of $134.3 \pm 0.8 \mathrm{Ma}$, compatible with previous age determinations. However, ages obtained in the basaltic flows indicate the duration of the volcanism to be around $3 \mathrm{Ma}$, which is consistent with paleomagnetic data presented by Ernesto and Marques (2004).

Thus far, the presence of sediments (sandstones of the Botucatu Formation) intercalated in the volcanic sequence was only reported in the lower basaltic pile. These consist of sand bodies presenting aeolian structures such as bypass surfaces, single dunes, sand-filled cracks and multi-dune ergs (Jerram and Stollhofen, 2002; Petry et al., 2007; Waichel et al., 2008), representing a desert environment that persisted during the voluminous initial phase of basaltic volcanism. In this work, the occurrence of sedimentation and development of associated peperites in the final stage of the PMP (Paraná Magmatic Province) volcanic event is presented. The sediments, predominantly sandy-silty, and unrelated to the Botucatu Formation, indicate a change in the environmental conditions in the Paraná Basin, and attest to the occurrence of significant periods of quiescence during the final stages of the magmatic activity.

\section{Petrographic and geochemical aspects of silicic volcanic rocks}

The Palmas-type silicic volcanic rocks (ATP) are characterized by light-gray to brownish-red color, hypohyalineholohyaline, aphyric to micro-porphyritic textures and a striking salt-and-pepper aspect, with some holohyaline units (pichstones) displaying black color, glassy luster and 
prominent conchoidal fractures. However, due to its amorphous nature, the glass is easily altered and thus in most outcrops the rock is completely weathered, presenting a brownish color and (often resembling sedimentary deposits) dotted with abundant vesicles and quartz-filled amygdales up to $10 \mathrm{~mm}$ in length. The mineralogy is composed of microphenocrysts (granularity smaller than $0.2 \mathrm{~mm}$ ) of plagioclase (labradorite) - which comprise up to $16 \%$ of the total volume of the rock $-11 \%$ of augite, $3 \%$ of pigeonite, $5 \%$ of magnetite and less than $1 \%$ of apatite. These crystals may exhibit rapid cooling structures (quenching), developing skeletal, lath and hollow shapes, or swallowtail terminations. The matrix reaches $63 \%$ of the rock volume on average, and is composed of dark-brown, slightly birefringent glass, characterized by a granophyric texture of abundant microlites, and alkali feldspar and quartz intergrowth that surrounds the crystal phases.

The Chapecó-type silicic volcanic rocks (ATC) are porphyritic, with an average of $24 \%$ of plagioclase phenocrysts up to $2 \mathrm{~cm}$ long, in a light-gray (when fresh) to brown (when weathered) aphanitic matrix. The mineralogy consists of euhedral andesine phenocrysts in a matrix composed of $4.5 \%$ of augite, $2.2 \%$ of pigeonite, $3.7 \%$ of magnetite, and $1.7 \%$ of apatite (average composition) surrounded by quartz and alkali feldspar fabric in felsitic, locally granophyric, arrangement (vitrophyric texture).

The chemical composition of the silicic volcanic rocks of the PMP, according to Nardy et al. (2008), show two main groups that may be observed in an R1 $\times$ R2 diagram (Fig. 2; De La Roche et al., 1980). The first one, the low-Ti suite, belongs to the tholeiitic field (tholeiitic basalts, andesi-basalts and andesites) associated with the Palmas-type silicic volcanic rocks, which belong to the rhyodacite and rhyolite fields. The second group, the high-Ti suite, is displaced towards the transitional field (transitional basalt, lati-basalt and latites). The Chapecó-type silicic volcanic rocks belong to this group in the rhyodacite and quartz latite fields (Fig. 2). The bulk-rock representative compositions for both Palmas and Chapecó types are listed in Table 1.

According to Bellieni et al. (1984a) the chemistry of the volcanic rocks and their spatial distribution allow the Paraná Basin to be schematically subdivided into three main regions: (1) southern, encompassing the tholeiitic suite in the southern Uruguay River alignment; (2) northern, where tholeiitic-transitional rocks occur in the northern Piquiri River alignment; and (3) central, located between the Piquiri and Uruguay River alignments, where both rock types are present (Fig. 1). The spatial distribution of the tholeiitic - ATP and transitional-tholeiitic-ATC suites indicates that acidic volcanic rocks may have been derived from the associated basalts, or ATC melts are derived from tholeiitictransitional basalts and ATP from tholeiitic basalts as suggested by Bellieni et al. (1986) and Garland et al. (1995).
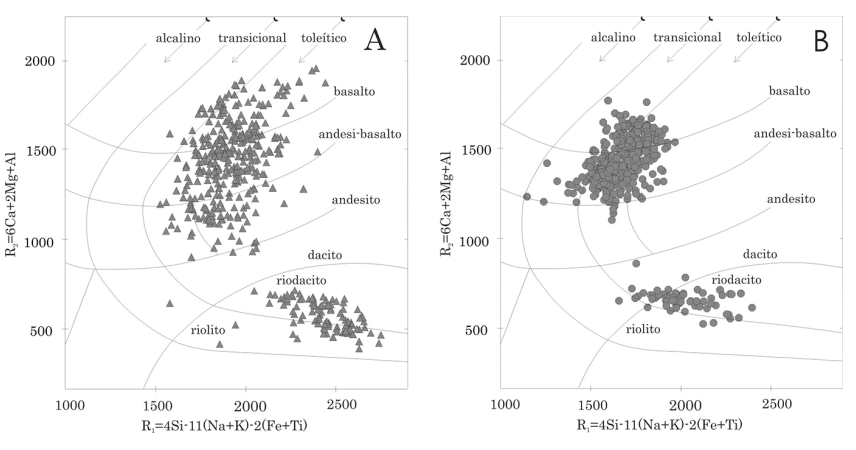

Fig. 2. $\mathrm{R} 1 \times \mathrm{R} 2$ diagram (De La Roche et al., 1980). (A) Tholeiitic suite (Low-Ti basalts and ATP), and (B) tholeiitic-transitional suite (High-Ti basalts and ATC).

\section{Stratigraphy}

The $1600 \mathrm{~m}$ thick PMP volcanic sequence consists of up to 32 lava flows of predominantly basic to intermediate compositions (tholeiitic basalts, andesi-basalts and andesites), as well as felsic volcanic rocks (dacites, rhyodacites and rhyolites; Bellieni et al., 1984, 1986).

The base of the stratigraphic column is composed of a thick sequence of basic to intermediate flows that overlap the aeolian sandstones of the Botucatu Formation. The sandstones may also occur interlayered in the first hundred meters of the basaltic pile. The Palmas and Chapecó Members overlap the basalt flows. The Palmas Member is characterized by silicic volcanic bodies (ATP type) associated with a few basaltic lava flows and crops out from the central region of the basin southwards, where it may reach a thickness of $270 \mathrm{~m}$. The Chapecó Member, composed of silicic volcanic rocks (ATC type), occurs in the northern and central regions of the Paraná Basin, the largest thickness, reaching $250 \mathrm{~m}$, being present in the central region. This Member overlaps the basalts, but in the northern portion of the basin (Paranapanema River region - SP), it is found directly on the sandstones of the Botucatu Formation.

In the center of the basin the two silicic Members overlap, indicating that the Palmas Member is older than Chapecó, although ATP-type rocks may be found interlayered in the Chapecó Member.

The last pulses of PMP volcanism emplaced basalt flows that cover both the Palmas- and Chapecó-type rocks and become thicker towards the northern area of the basin.

\subsection{Peperites and sedimentary deposit}

The literature (Marques and Ernesto, 2004; Thiede and Vasconcellos, 2011) indicates that the PMP magmatism occurred quickly, during a time interval that did not exceed $3 \mathrm{Ma}$, and in a rather continuous way, based on a few occurrences of sedimentary intercalations or paleosoils within the volcanic sequence. However, recent field work has revealed the 
Table 1. Representative analysis of Palmas and Chapecó silicic volcanics of the PMP (major elements, in oxide wt \%; trace elements, in ppm).

\begin{tabular}{|c|c|c|c|c|c|c|c|c|}
\hline \multirow[b]{2}{*}{ Sample } & \multicolumn{5}{|c|}{ Palmas } & \multicolumn{3}{|c|}{ Chapecó } \\
\hline & $\mathrm{KC}$ & KSE & KSE & $\mathrm{KS}$ & KSU & $\mathrm{KC}$ & PU & $\mathrm{KNO}$ \\
\hline No. & 505 & 406 & 419 & 319 & 237 & 482 & 1011 & 442 \\
\hline $\mathrm{SiO}_{2}$ & 65.48 & 66.44 & 67.58 & 68.70 & 70.46 & 64.38 & 65.44 & 66.93 \\
\hline $\mathrm{TiO}_{2}$ & 1.11 & 0.96 & 0.95 & 0.95 & 0.71 & 1.46 & 1.57 & 1.24 \\
\hline $\mathrm{Al}_{2} \mathrm{O}_{3}$ & 12.96 & 12.74 & 12.35 & 12.12 & 12.38 & 12.83 & 13.03 & 13.03 \\
\hline $\mathrm{Fe}_{2} \mathrm{O}_{3}$ & 6.78 & 6.15 & 6.15 & 5.69 & 5.22 & 7.01 & 7.57 & 6.54 \\
\hline $\mathrm{MnO}$ & 0.08 & 0.11 & 0.20 & 0.10 & 0.09 & 0.16 & 0.12 & 0.10 \\
\hline $\mathrm{MgO}$ & 1.08 & 1.70 & 1.22 & 1.28 & 0.61 & 1.36 & 1.28 & 0.75 \\
\hline $\mathrm{CaO}$ & 2.78 & 2.93 & 3.09 & 2.68 & 2.20 & 2.91 & 2.94 & 2.07 \\
\hline $\mathrm{Na}_{2} \mathrm{O}$ & 3.64 & 2.87 & 2.78 & 2.30 & 2.92 & 3.32 & 3.61 & 3.36 \\
\hline $\mathrm{K}_{2} \mathrm{O}$ & 4.01 & 3.89 & 4.17 & 4.69 & 4.74 & 4.45 & 4.33 & 4.61 \\
\hline $\mathrm{P}_{2} \mathrm{O}_{5}$ & 0.33 & 0.27 & 0.26 & 0.26 & 0.20 & 0.48 & 0.46 & 0.33 \\
\hline LOI & 1.93 & 1.91 & 1.01 & 0.99 & 0.57 & 1.05 & 0.61 & 1.63 \\
\hline SUM & 100.17 & 99.98 & 99.75 & 99.76 & 100.09 & 99.41 & 100.96 & 100.60 \\
\hline $\mathrm{Cu}$ & 128 & 75 & 78 & 63 & 18 & 7 & 9 & 14 \\
\hline $\mathrm{Ni}$ & 7 & 8 & 7 & 8 & 3 & 4 & 5 & 5 \\
\hline $\mathrm{Ba}$ & 610 & 706 & 694 & 588 & 613 & 1076 & 1003 & 1199 \\
\hline $\mathrm{Rb}$ & 169 & 160 & 165 & 175 & 206 & 100 & 101 & 136 \\
\hline $\mathrm{Sr}$ & 135 & 143 & 127 & 137 & 102 & 360 & 337 & 318 \\
\hline $\mathrm{Zr}$ & 279 & 258 & 252 & 266 & 319 & 633 & 670 & 592 \\
\hline $\mathrm{Y}$ & 63 & 41 & 57 & 42 & 55 & 65 & 66 & 60 \\
\hline $\mathrm{Nb}$ & 22 & 20 & 20 & 21 & 23 & 48 & 51 & 44 \\
\hline $\mathrm{U}$ & 3.51 & 4.07 & 4.04 & 4.17 & 3.25 & 1.74 & 1.91 & 2.68 \\
\hline Th & 11.53 & 11.30 & 11.64 & 12.09 & 12.25 & 8.76 & 8.62 & 12.69 \\
\hline $\mathrm{La}$ & 42.0 & 35.0 & 36.1 & 36.0 & 43.2 & 60.4 & 63.7 & 67.8 \\
\hline $\mathrm{Ce}$ & 88.0 & 76.0 & 78.0 & 73.0 & 95.5 & 144.6 & 147.0 & 145.0 \\
\hline $\mathrm{Nd}$ & 46.0 & 36.0 & 34.8 & 34.0 & 42.7 & 68.4 & 71.7 & 70.9 \\
\hline $\mathrm{Sm}$ & 9.40 & 7.00 & 7.47 & 7.10 & 8.78 & 15.78 & 15.10 & 14.50 \\
\hline $\mathrm{Eu}$ & 2.02 & 1.66 & 1.53 & 1.53 & 1.60 & 3.60 & 3.52 & 3.11 \\
\hline $\mathrm{Gd}$ & 9.80 & 7.30 & 7.28 & 8.10 & 8.78 & 14.04 & 13.10 & 11.90 \\
\hline Dy & 8.30 & 6.90 & 7.43 & 7.40 & 8.32 & 10.83 & 11.50 & 10.20 \\
\hline Ho & 1.70 & 1.40 & & 1.60 & & & & \\
\hline $\mathrm{Er}$ & 4.70 & 4.00 & 4.54 & 4.60 & 5.25 & 5.97 & 6.21 & 5.42 \\
\hline $\mathrm{Yb}$ & 4.50 & 3.40 & 3.92 & 3.70 & 4.61 & 4.79 & 5.03 & 4.39 \\
\hline $\mathrm{Lu}$ & 0.60 & 0.50 & 0.61 & 0.60 & 0.71 & 0.65 & 0.76 & 0.65 \\
\hline
\end{tabular}

presence of frequent sediment lenses and peperites in various stratigraphic levels within the silicic volcanic sequence.

Peperite is a genetic term used for rocks formed in situ by the interaction between hot magma (intrusive bodies, lava or pyroclastic flows) and coeval wet sediments (Fisher, 1960; Williams and McBirney, 1979; White et al., 2000; Skilling et al., 2002). Nonetheless, some authors (e.g., Jerram et al., 1999; Jerram and Stollhofen) have also described an interaction with dry sediments. Peperite is classified into two basic types according to the shape of its elements (BusbySpera and White, 1987): blocky, in which the volcanic clasts present angular shapes and show a jigsaw-fit texture reflecting in situ quench fragmentation in a brittle state, and fluidal in which volcanic clasts present irregular, fluid (amoeboid), globular to undefined shapes, reflecting a ductile state dur- ing fragmentation, with the sediment often filling vesicles and being injected into cracks in the volcanic clasts/rocks, although more complex shapes may also be found (McPhie et al., 1993; Skilling et al., 2002).

Sedimentary deposits and peperites found in the Chapecó and Palmas members present a wide distribution in the Paraná Basin, as shown in Fig. 3, and are described below.

In the São Jerônimo da Serra (Paraná State) region, in the northern sector of the Paraná Basin, ATC-type rocks overlap a sandstone forming blocky peperite (Fig. 4). The blocky peperite is comprised of clastic dikes, which can be from a few centimeters to just over $1 \mathrm{~m}$ thick (Fig. 4a), and breccias, composed of matrix-supported angular to rounded volcanic blocks of variable size (Fig. 4b). The sandstone is poorly sorted with angular to rounded quartz grains (Fig. 4c and d), 


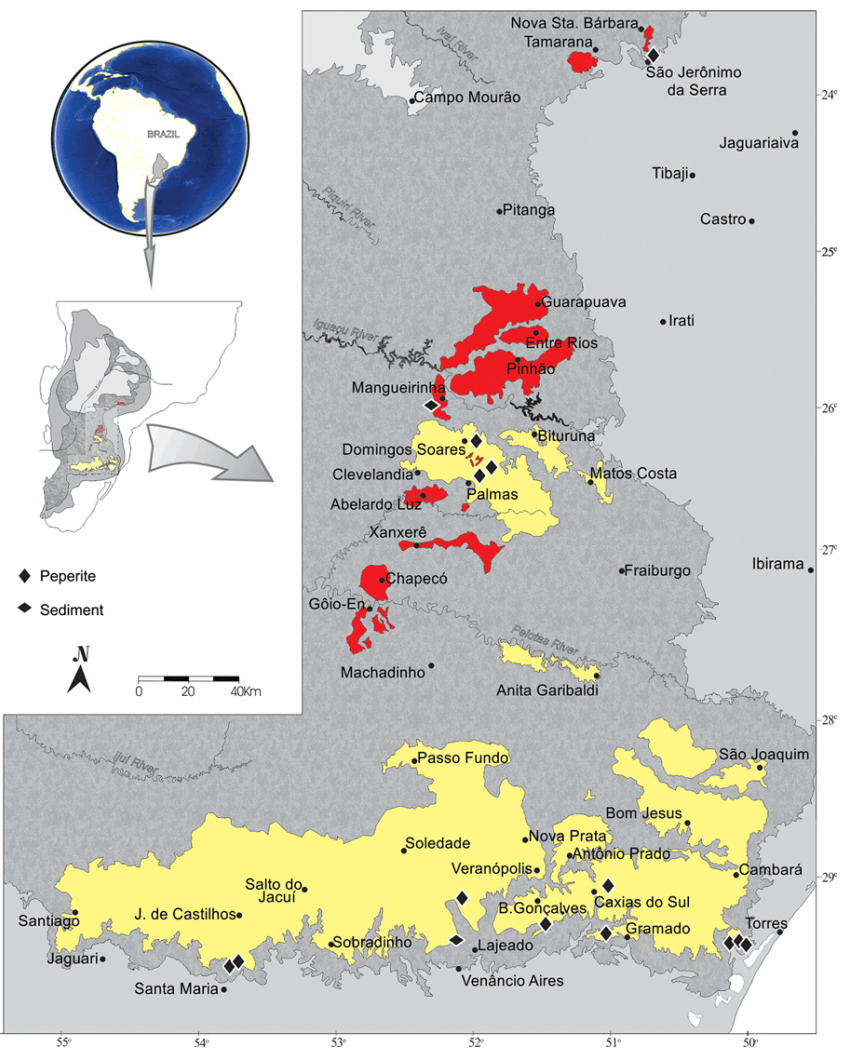

Fig. 3. Map with the location of sediment and peperite outcrops (lozenges) within the Palmas and Chapecó Members: yellow - ATP units; red - ATC units.

and it was silicified by thermal metamorphism by the overlying volcanic material.

In the region of Mangueirinha and Palmas (Paraná State), in the center of the basin, both ATC- and ATP-type rocks crop out as either overlying basalts or overlapping each other. A sandstone layer was observed intercalated between ATC-type silicic body and an overlying basaltic lava flow. The base of the sediment is a breccia formed by vesicular ATC clasts set in a sandy matrix, implying some erosion degrees of the top of the volcanic body during sedimentation. In another location, an ATC-type silicic unit overlies a vesicular ATP-type silicic body, with a red clayey-silty sediment intercalated between the two units. The sediment was injected upwards into fractures in the overlying ATC unit forming peperite with both fluidal and blocky features (Fig. 5a and b), while in the underlying ATP unit, the sediment filled cooling cracks without any peperitic interaction (figure $5 c$ and d). In a third exposure, a reddish-brown silty sediment, intercalated between two ATP volcanic units, formed peperite with blocky jointing morphology (Skilling et al., 2002), characterized by the injection of sediment into centimeter- to millimeter-spaced joints in the base of the overlying volcanic unit (Fig. 6).

In the southern region of the Paraná Basin (Rio Grande do Sul State), sediments and peperites were observed between

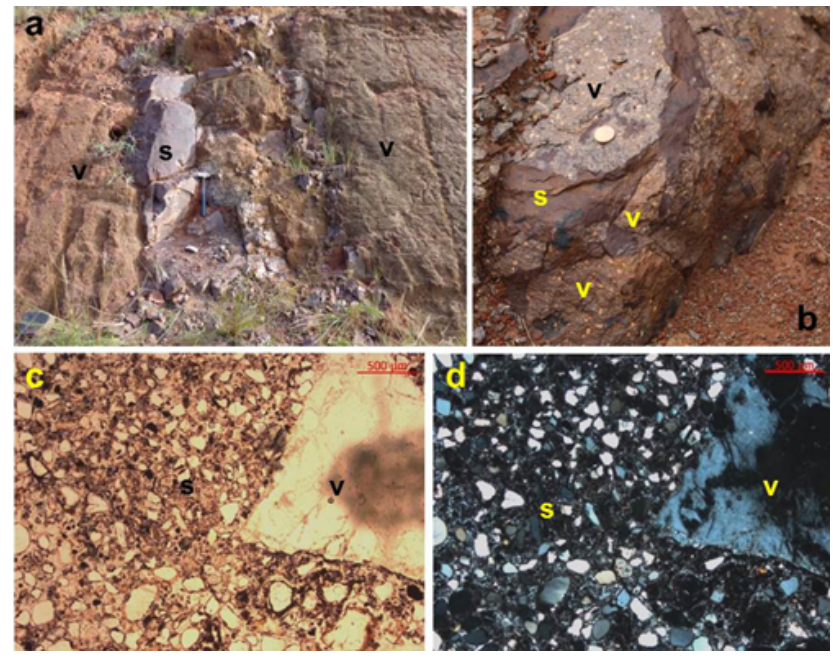

Fig. 4. Peperite from São Jerônimo da Serra: $(\mathbf{a}, \mathbf{b})$ photomicrographs of the immature and poorly sorted sediment $(\mathbf{c}=/ /$ polarizers; $\mathbf{d}=X$ polarizers), (c) clastic dike more than $1 \mathrm{~m}$ thick, and $\mathbf{d}$ angular to sub-angular shaped clasts set in a sandstone matrix. $\mathrm{S}-$ sandstone; $\mathrm{V}$ - volcanic rock.

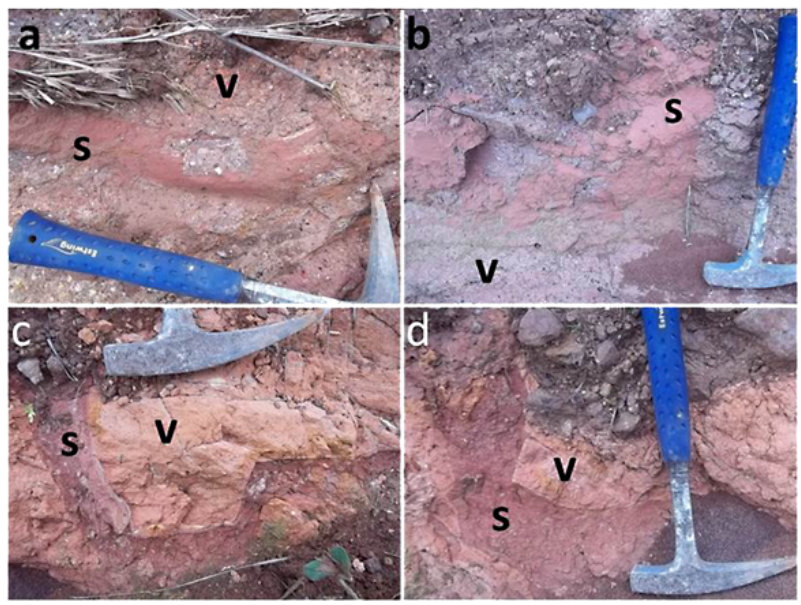

Fig. 5. Silicic ATC- and ATP-type rocks (V) in contact with red clayey siltstone $(\mathrm{S})$ : $(\mathbf{a}, \mathbf{b})$ peperites in the base of an ATC-type rock; (c and d) fractures in the top of an ATP-type rock filled with sediment, in the central region of the Paraná Basin.

some basaltic lower units and the overlying Palmas silicic sequence. In the Santa Maria region, blocky peperite was observed in the base of the lowermost silicic volcanic unit. The peperite displays a well-developed jigsaw-fit texture, and closely packed, blocky to cuneiform juvenile clast shapes of several sizes, separated by an orange-colored sedimentary material (Fig. 7). The sediment exhibits a high degree of baking (thermal metamorphism), and the juvenile clasts show intense devitrification, indicating very high temperature of the volcanic material interacting with the sediment. 


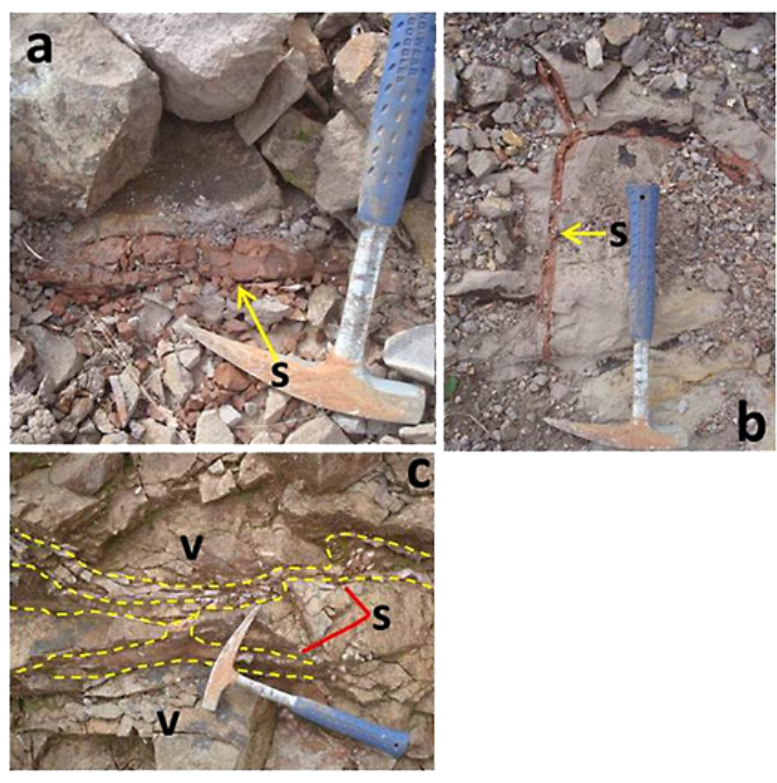

Fig. 6. Blocky jointed peperite in the base of an ATP-type unit (Domingos Soares city - Paraná State, central region of the Paraná Basin): V - ATP rock; $\mathrm{S}$ - sediment.

Near the city of Venâncio Aires, a $10 \mathrm{~m}$ thick sedimentary layer underlies an ATP silicic volcanic unit. The sediment is a reddish-colored sandstone composed of sub-angular to rounded quartz grains (Fig. 8). The volcanic unit presents a well-developed horizontal jointed base and the contact with the sandstone is sharp, apparently lacking peperitic interaction (Fig. 8).

A road cut on the Soledade to Lajeado highway exposes a peperite in the base of a $25 \mathrm{~m}$ thick basaltic lava flow interlayered within the ATP silicic volcanic sequence. Volcanic clasts in the peperite are vesicular and display a variety of morphologies, from blocky to fluidal. The sediment is a red, poorly sorted sandstone, which partially fills vesicles in the volcanic clasts.

Eastward, in the area between Bento Gonçalves and Cambará do Sul (Rio Grande do Sul), all the observed peperites are interlayered within the silicic volcanic sequence and the sedimentary material becomes finer and predominantly silty. A peperite was observed in a quarry floor in Nova Petrópolis, near the city of Gramado, resulting from the interaction of sediment with a thin $(\sim 1$ m thick) amygdaloidal basalt interlayered in the silicic volcanic sequence. It displays blocky juvenile clasts with irregular shapes separated by orange to reddish, poorly sorted fine-grained sandstone. The sediment presents vesicles that probably resulted from volatilization of sediment water by heating (Fig. 9).

On the Rota do Sol highway, connecting Caxias do Sul to the coast, three peperite levels were observed interlayered in a sequence of black and glassy volcanic units of the Palmas Member. The stratigraphically lower two are sim-

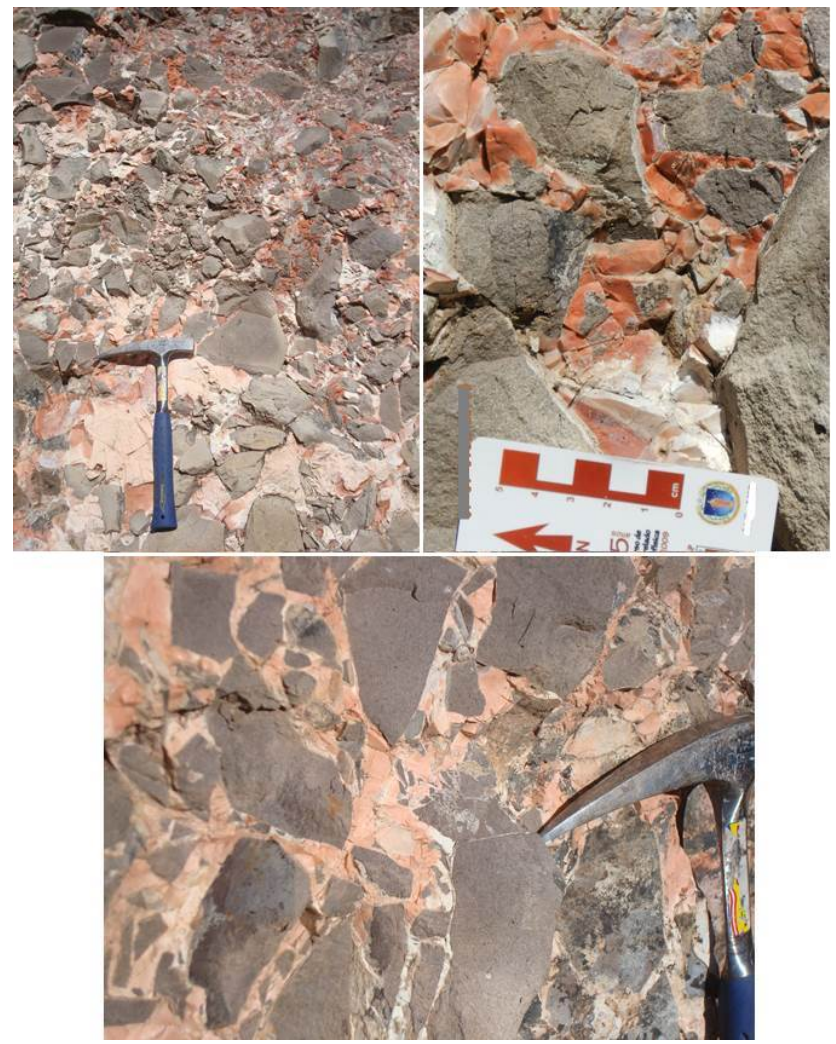

Fig. 7. Blocky peperite formed by interaction of an ATP-type volcanic body with sediment in the Santa Maria region (Rio Grande do Sul State): well-developed jigsaw-fit texture, closely packed, gray blocky to cuneiform clasts of variable sizes, separated by orange sedimentary material, displaying intense baking.

ilar and characterized by vesicular, pale to greenish and glassy volcanic clasts, presenting angular to rounded irregular shapes (Fig. 10). The sedimentary material is a brown, moderate to poorly sorted siltstone that also fills vesicles in volcanic clasts. The uppermost peperite presents juvenile volcanic clasts with a wide variety of morphologies, the fluidal shapes being more frequent (Fig. 11). The green and vesicular volcanic clasts are surrounded by a reddish-brown siltstone, which also fills vesicles and fractures in volcanic clasts (Fig. 11d). It is slightly coarser and more poorly sorted than the previous two sediments (Fig. 12), and many clasts of the stratigraphically lower peperite display perlitic fractures (Fig. 12c).

\section{Discussion and concluding remarks}

The PEMP (Paraná-Etendeka Magmatic Province) is considered one of the largest LIPs (large igneous provinces) of continental crust in the world, encompassing an area of nearly 1 million cubic kilometers (Bryan et al, 2010). Of total volume of the volcanic products, $95 \%$ are preserved in the South American continent, in the PMP. All volcanic material 


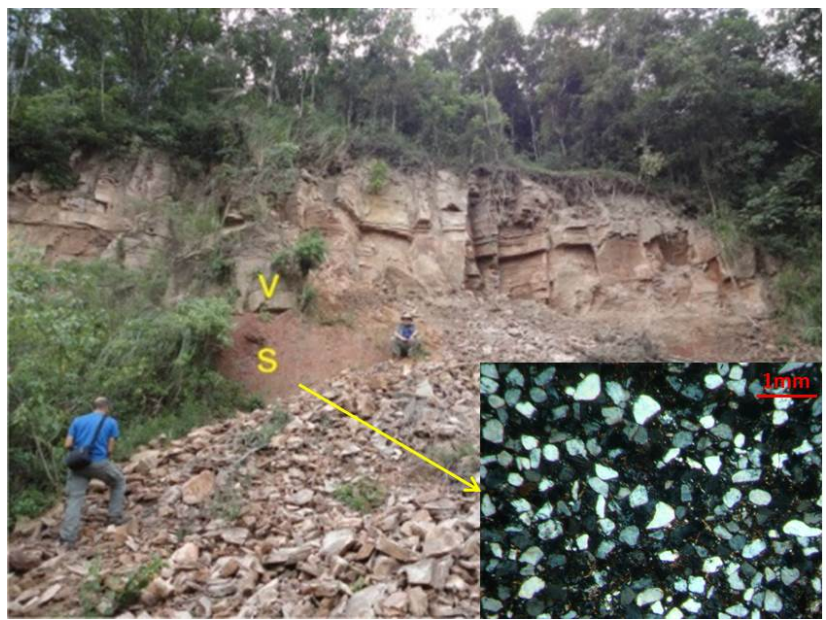

Fig. 8. Outcrop in the Venâncio Aires area (Rio Grande do Sul State), where a silicic volcanic unit of the ATP type (V) rests on a reddish sedimentary layer $(S)$ lacking peperitic interaction. On the right lower corner a photomicrograph of the sandstone ( $X$ polarizers).
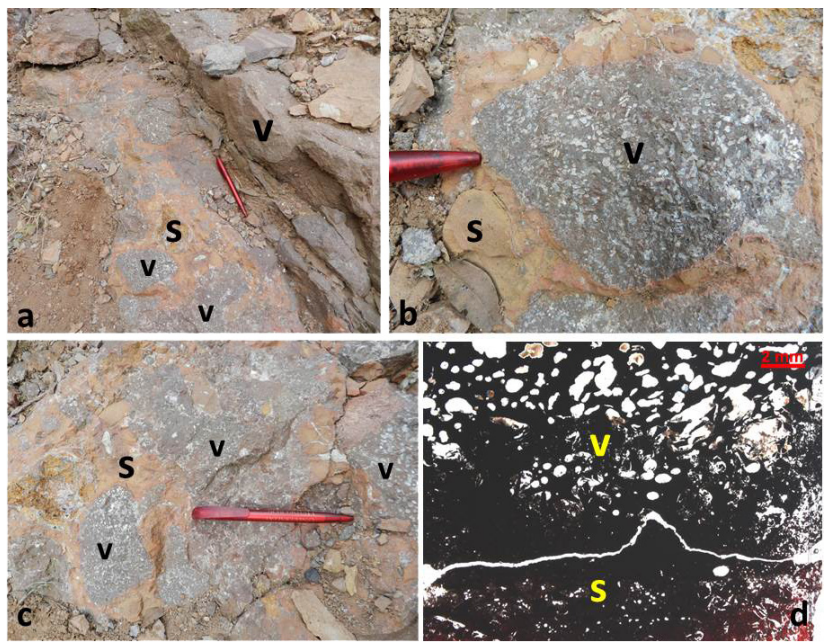

Fig. 9. Aspects of a peperite produced by interaction of a thin basalt flow (within the silicic Palmas Member) and fine-grained sediment near Nova Petrópolis (Rio Grande do Sul State), southern part of the basin: (a-c) irregular blocky volcanic clasts (V) in a reddish sandstone matrix (S), and (d) photomicrograph showing the amygdaloidal basalt $(\mathrm{V})$ in the upper part and a poorly sorted fine-grained sandstone in the bottom (S).

was erupted in a short period of time $(\sim 3$ million years $)$ without significant interruption, as deduced from the scarcity of sediments interlayered within the volcanic sequence. In fact, and up to now, the only references to the presence of sediments interbedded within the volcanics corresponded to layers or lenses of sandstones (intertraps), a few centimeters to several meters thick, from the Botucatu Formation. These occur only in the base of the lava flow pile in both the African (Jerram et al., 1999, 2000; Jerram and Stollhofen,

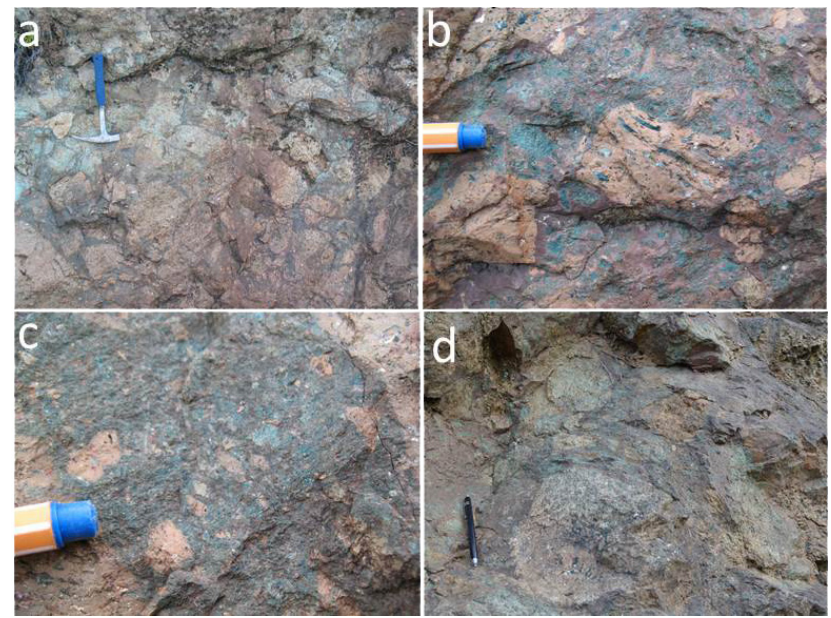

Fig. 10. Aspects of the two lowermost peperites in the Palmas volcanic sequence, along the Rota do Sol highway (Rio Grande do Sul State): images of the lowermost peperite $(\mathbf{a}, \mathbf{b}$, and $\mathbf{c})$ and of the middle peperite (d). The volcanic clasts are pale and light or dark green, while the siltstone is dark brown.
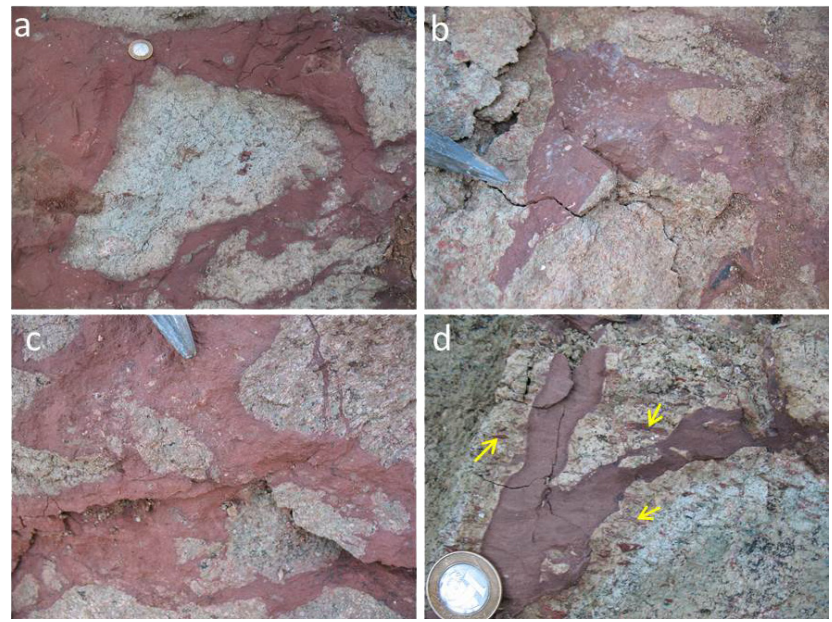

Fig. 11. Peperite from the stratigraphically higher level on the section exposed in the Rota do Sol highway: green to pale volcanic clasts, displaying sub-angular to irregular morphologies, set in a reddish-brown siltstone matrix, which also fills vesicles in volcanic clasts (yellow arrows in $\mathbf{d}$ ).

2002) and South American continents (Petry et al., 2007; Waichel et al., 2008). Sandstone intertraps in rhyodacites in the Piraju-Ourinhos region (São Paulo State; Janasi et al., 2007; Luchetti, 2010), where the thick basaltic sequence is missing, were also known. However, until now, there were no reports of features indicating significant time breaks in the upper part of the PMP stratigraphic sequence.

New observations of the occurrence of sedimentary lenses and peperites, resulting from volcano-sedimentary interaction at the base and within the upper silicic sequences of the PMP are presented in this paper. Throughout the Paraná 


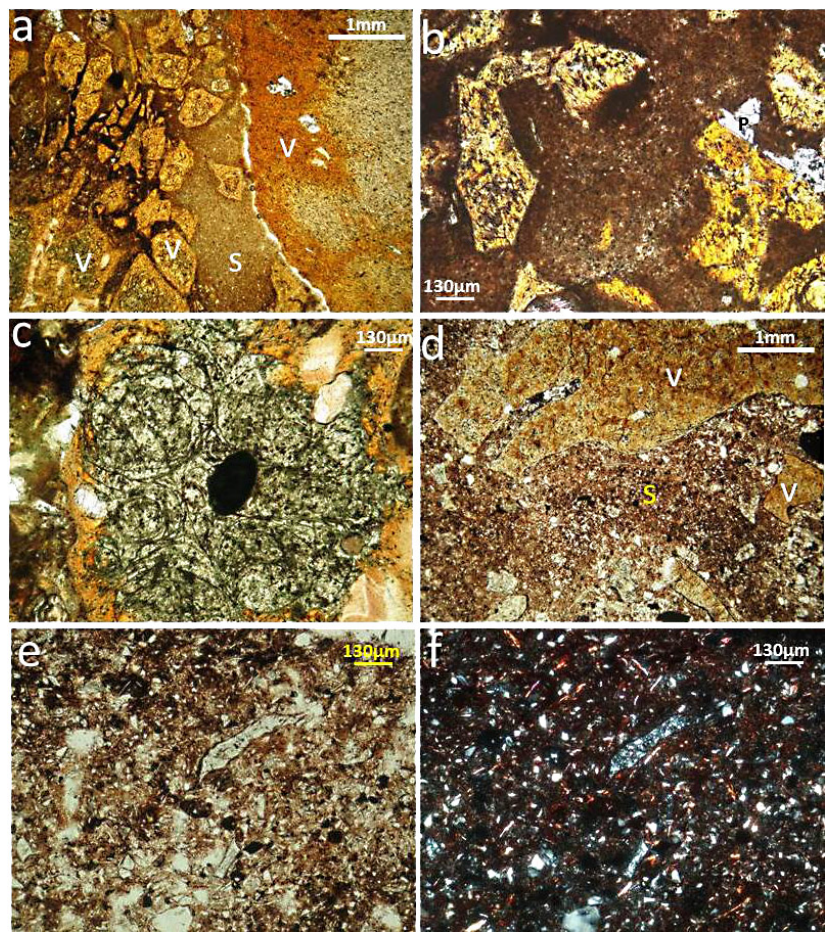

Fig. 12. Photomicrographs of peperites from the Palmas volcanic sequence, along Rota do Sol highway: (a, b and d) volcanic glassy clasts (V) set in a brown siltstone matrix (S); (c) volcanic clast displaying concentric fractures - perlitic texture - common in the two lowermost peperites; (e and $\mathbf{f}$ ) detail of the poorly sorted, slightly coarser siltstone from $(\mathbf{d})(\mathbf{a}, \mathbf{b}, \mathbf{c}, \mathbf{d}$ and $\mathbf{e}-/ /$ polarizers; $\mathbf{f}-X$ polarizers; $\mathrm{P}=$ plagioclase).

Basin these were observed associated with silicic and basaltic units of the Palmas and Chapecó Members.

Some works on the PMP report peperites derived from the basalt-flow-sediment interaction (Petry et al., 2007; Waichel et al., 2007, 2008), the most common types found in worldwide volcanic sequences. Nevertheless, structures observed in this study reveal that this interaction also occurred between silicic extrusive bodies and wet sediment. These "silicic peperites" are mostly blocky, highlighting a more viscous magma (Dadd and Wagoner, 2002). However, they may also display fluidal features, which indicate less viscous melts, likely due to higher temperatures $\left(>1000^{\circ} \mathrm{C}\right.$; Piccirillo and Melfi, 1988).

The sediments display immature features, suggesting limited transport and, depending on the location, range from moderately to poorly sorted sandstones to siltstones. There was often lava-sediment interaction producing peperites or sediment deformation by the weight of overlying volcanic units. Evidence for the presence of wet and unconsolidated or poorly consolidated sediments is the variety of morphologies found, injections of sediment into fractures, vesicles in the juvenile clast filled by sediment and vesiculated sediment (Skilling et al., 2002).
Paleoenvironment climatic conditions at the time of the PMP volcanism were quite dry, since the Serra Geral Formation overlies the Botucatu Formation, described as a dry aeolian system (Sherer, 2000). Sandstone lenses up to $20 \mathrm{~m}$ thick interlayered in the first basalt lava flows (Jerram et al., 1999, 2000; Jerram and Stollhofen, 2002; Petry et al., 2007; Waichel et al., 2008) reveal that this system remained active during the magmatic event. However, new evidence of wet and locally silty sediment between basalt and silicic units and interlayered in the silicic units (end of the volcanic sequence) presented here reflect a paleoenvironmental change, from a dry climate in the beginning of the PMP volcanic activity to a more humid environment (fluvial-lacustrine) during the latest phases of the magmatism, as also evidenced by Waichel et al. (2007) in peperites found in some basalt units of the PMP in contact with lacustrine sediments. In the São Jerônimo da Serra region, the northern area of the basin, the change must have started before the volcanism. Furthermore, this seems to be common in this type of setting in which humid and dry aeolian systems may alternate over time due to climate changes (Assine et al., 2004).

The deposition of sediments must have taken place in depressed portions of the paleorelief (small valleys or depressions of the original volcanic morphology), and suggests a decrease in eruptive frequency towards the end of the volcanic activity, allowing time for the deposition of sedimentary material between individual volcanic events.

In conclusion, the PMP volcanism was not completely continuous, but presented significant pauses, mainly in the initial and terminal phases. On the other hand, the occurrence of sediments separating the top of the lower basaltic sequence and the beginning of the silicic extrusions may represent a pause in the volcanic activity that coincides with the compositional change in the magmatism of the Paraná Magmatic Province.

Acknowledgements. This study was supported by São Paulo Research Foundation (FAPESP) and National Council of Technological and Scientific Development (CNPq). We thank Francisco Negri for help in fieldwork in the central basin and Dr. Scarlato, Piergiorgio, Dr. Giacomoni, Pier Paolo and an anonymous referee for valuable suggestions and review.

Edited by: P. Scarlato

\section{References}

Assine, M. L., Piranha, J. M., Carneiro, C. D. R.: Os paleodesertos Pirambóia e Botucatu, in: Geologia do Continente SulAmericano: evolução da obra de Fernando Flávio Marques de Almeida, edited by: Mantesso-Neto, V., Bartorelli, A., Carneiro, C. D. R., and Brito-Neves, B. B., SP, Brasil, Beca Prod Cult Ltda, 77-92, 2004.

Bellieni, G., Brotzu, P., Comin-Chiaramonti, P., Ernesto, M., Ernesto, M., Melfi, A. J., Pacca, I. G., and Piccirillo, E. M.: 
Flood basalt to rhyolites suites in the southern Paraná plateau (Brazil): paleomagnetism, petrogenis and geodynamic implications, J. Petrol., 25, 579-618, 1984.

Bellieni, G., Comin-Chiaramonti, P., Marques, L. S., Melfi, A. J., Nardy, A. J. R., Papatrechas, C., Piccirillo, E. M., and Roisenberg, A.: Petrogenetic aspects of acid and basaltic lavas from the Paraná plateau (Brazil): geological, mineralogical and petrochemical relationships, J. Petrol., 27, 915-944, 1986.

Bryan, S. E., Ukstins-Peate, I., Peate, D. W., Self, S., Jerram, D. A., Mawby, M. R., Marsh, J. S., and Miller, J. A.: The largest volcanic eruptions on Earth. Earth-Sci. Rev., 102, 207-229, 2010.

Busby-Spera, C. J. and White, J. D. L.: Variation in peperite textures associated with differing host sediment properties, B. Volcanol., 49, 765-775, 1987.

Dadd, K. A. and Van Wagoner, N. A.: Magma composition and viscosity as controls on peperite texture: an example from Passamaquoddy Bay, southeastern Canada, in: Peperite: Processes and Products of Magma-Sediment Mingling, edited by: Skilling, I. P., White, J. D. L., and McPhie, J., J. Volcanol. Geoth. Res., 114, 63-80, 2002.

De La Roche H., Leterrier P., Grandclaude P., and Marshal M.: A classification of volcanic and plutonic rocks using $\mathrm{R} 1 \times \mathrm{R} 2 \mathrm{dia}-$ gram and major element analysis. Its relationships with current nomenclature, Chem. Geol., 28, 183-210, 1980.

Ernesto, M., Raposo, M. I. B., Marques, L. S., Renne, P. R., Diogo, L. A., and De Min, A.: Paleomagnetism, geochemistry and 40ar/39ar dating of the north-eastern Paraná Magmatic Province, Tectonic implications, J. Geodyn., 28, 321-340, 1999.

Fisher, R. V.: Classification of volcanic breccias, Geol. Soc. Am. Bull., 71, 973-982, 1960.

Frank, H. T., Gomes, M. E. B., and Formoso, M. L. L.: Review of the areal extent and the volume of the Serra Geral Formation, Paraná Basin, South America, Pesquisas em Geociências, 36, 49-57, 2009.

Garland, F., Hawkesworth, C. J., and Mantovani, M. S. M.: Description and Petrogenesis of the Paraná Rhyolites, Southern Brazil, J. Petrol., 36, 1193-1227, 1995.

Janasi, V. A., Montanheiro, T. J., Freitas, V. A., Reis, P. M., Negri, F. A., and Dantas, F. A.: Geology, petrography and geochemistry of the acid volcanism of the Paraná Magmatic Province in the Piraju-Ourinhos region, SE Brazilian, J. Geosci., 37, 745-759, 2007.

Janasi, V. A., Freitas, V. A., and Heaman, L. H.: The onset of ?ood basalt volcanism, Northern Paraná Basin, Brazil: A precise U-Pb baddeleyite/zircon age for a Chapecó-type dacite, Earth. Planet. Sc. Lett., 302, 147-153, 2011.

Jerram, D. A., Mountney, N., and Stollhofen, H.: Facies architecture of the Etjo Sandstone Formation and its interaction with the Basal Etendeka food basalts of NW Namibia: Implications for offshore analogues, in: The Oil and Gas Habitats of the South Atlantic, edited by: Cameron, N., Bate, R., and Clure, V., Geological Society, London, Special Publications, 153, 367-380, 1999.

Jerram, D. A., Mountney, N., Howell, J., Long, D., and Stollhofen, H.: Death of a Sand Sea: an active erg systematically buried by the Etendeka flood basalts of NW Namibia, J. Geol. Soc. London, $157,513-516,2000$.
Jerram, D. A. and Stollhofen, H.: Lava-sediment interaction in desert settings; are all peperite like textures the result of magmawater interaction?, J. Volcanol. Geoth. Res., 114, 231-49, 2002.

Luchetti, A. C. F.: Aspectos vulcanológicos dos traquidacitos da região de Piraju-Ourinhos (SP) [Master Dissertation], São Paulo, SP, Brazil, Universidade de São Paulo, 92 pp., 2010.

Malagutti, M. I. A., Bahia F, Moreno, M. M. T., and Nardy, A. J. R.: Determinação de elementos terras raras e ítrio em rochas silicáticas por ICP-OES com separação em resina trocadora de íons, Geochem. Bras., 12, 75-80, 1998.

Marques, L. S. and Ernesto, M.: O magmatismo toleítico da Bacia do Paraná, in: Geologia do Continente Sul-Americano, edited by: Mantesso-Neto, V., Bartorelli, A., Carneiro, C. D. R., and BritoNeves, B. B., Beca Produções Culturais Ltda, 2004.

McPhie, J., Doyle, M., and Allen, R.: Volcanic textures: a guide to the interpretation of textures in volcanic rocks, University of Tasmania, 197 pp., 1993.

Milner, S. C., Duncan, A. R., and Ewart, A.: Quartz latite rheoignimbrite flows of the Etendeka Formation, north western Namibia, B. Volcanol., 54, 200-219, 1992.

Mincato, R. L., Enzweiler, J., and Schrank, A.: Novas idades ${ }^{39} \mathrm{Ar} /{ }^{40} \mathrm{Ar}$ e implicações na metalogênese dos depósitos de sulfetos magmáticos de Ni-Cu-EPG na Província Ígnea Continental do Paraná, in: 9th Brazilian Congress of Geochemistry, Belém (Pará), Brazil, 2-9 November 2003, 67-92, 2003.

Nardy, A. J. R., Enzweiler, J., Bahia F, O., Oliveira, M. A. F., and Peneiro, M. A. V.: Determinação de elementos maiores e menores em rochas silicáticas por espectometria de fluorescência de raios-x: resultados preliminares, in: 6th Brazilian Congress Of Geochemistry, Salvador (Bahia), Brazil, 346-348, 1997.

Nardy, A. J. R., Oliveira, M. A. F., Betancourt, R. H. S., Verdugo, D. R. H., and Machado, F. B.: Geologia e estrtigrafia da Formaçõ Serra Geral, Revista Geociências, 21, 15-32, 2002.

Nardy, A. J. R., Machado, F. B., and Oliveira, M. A. F.: As rochas vulcânicas mesozóicas ácidas da Bacia do Paraná: litoestratigrafia e considerações geoquímico-estratigráficas, Brazil. J. Geosci., 38, 178-195, 2008.

Peate, D., Hawkesworth, C. J., and Mantovani, M. S. M.: Chemical Stratigraphy of the Paraná Lavas (South America): Classification of Magma Types and their Spatial Distribution, B. Volcanol., 55, 119-139, 1992.

Petry, K., Jerram, D. A., De Almeida, D. P. M., Zerfass, H.: Volcanic-sedimentary features in the Serra Geral Fm., Paraná Basin, southern Brazil: Examples of dynamic lava-sediment interactions in an arid setting, J. Volcanol. Geoth. Res., 159, 313325, 2007.

Piccirillo, E. M. and Melfi, A. J. (Eds.): The Mesozoic Flood Volcanism of the Paraná Basin: Petrogenetic and Geophysical Aspects, Instituto Geofísico, Astronômico e Ciências Atmosféricas, Universidade de São Paulo, São Paulo, Brazil, 1988.

Renne, P. R., Ernesto, M., Pacca, I. G., Coe, R. S., Glen, J. M., Prévot, M., and Perrin, M.: The age of Parana flood volcanism, rifting of Gondwanaland, and the Jurassic-Cretaceous boundary, Science 258, 975-979, 1992.

Renne, P. R., Deckart, K., Ernesto, M., Féraud, G., and Piccirillo, E. M.: Age of the Ponta Grossa dyke swarm (Brazil), and implications to Paraná flood volcanism, Earth. Planet. Sc. Lett. 144, 199-211, 1996a. 
Renne, P. R., Glen, J. M., Milner, S. C., Duncan, A. R.: Age of Etendeka flood volcanism and associated intrusions in southwestern Africa, Geology 24, 659-662, 1996b.

Santos, R. N., Marques, L. S., Brenha-Ribeiro, F., and Nicola, S. H. A.: Determination of uranium concentrations and activity ratios in silicate rocks by alpha spectrometry: application to volcanic rocks from Trindade and Martin Vaz Islands, Appl. Radiat. Isot., 56, 741-750, 2002.

Santos, R. N., Marques, L. S., Brenha-Ribeiro, F., and Nicola, S. H. A.: Determination of thorium concentrations and activity ratios in silicate rocks by alpha spectrometry, Appl. Radiat. Isot., 56, 741-750, 2004.

Scherer, C.: Aeolian dunes of the Botucatu Formation (Cretaceous) in southernmost Brazil: morphology and origin, Sed. Geol., 137, 63-84, 2000.

Skilling, I. P., White, J. D. L., and Mcphie, J.: Peperite: a review of magma-sediment mingling, J. Volcanol. Geoth. Res., 114, 1-17, 2002.

Sun, S. and Mcdonough, W. F.: Chemical and isotopic systematics of oceanic basalts: implications for mantle composition and processes, in: Magmatism in the Ocean Basins, edited by: Saunders A. D. and Norry M. J., Geol. Soc. London, 1, London, 313-345, 1989.
Thiede, D. S. and Vasconcelos, P. M.: Paraná flood basalts: rapid extrusion hypothesis confirmed by new ${ }^{40} \mathrm{Ar} /{ }^{39} \mathrm{Ar}$ results, Geology, 38, 747-750, 2010.

Turner, S., Regelous, M., Kelley, S., Hawksworth, C., and Mantovani, M. M. S.: Magmatism and continental break-up in the South Atlantic: high precision ${ }^{40} \mathrm{Ar} /{ }^{39} \mathrm{Ar}$ geochronology, Earth Plan. Sci. Lett., 121, 333-348, 1994.

Waichel, B. L., Lima, E. F., Sommer, C. A., and Lubachesky, R.: Peperite formed by lava flows over sediments: An example from the central Paraná Continental Flood Basalts, Brazil, J. Volcanol. Geoth. Res., 159, 343-354, 2007.

Waichel, B. L., Scherer, C. M. S., and Frank, H. T.: Basaltic lava flows covering active aeolian dunes in the Paraná Basin in southern Brazil: Features and emplacement aspects, J. Volcanol. Geoth. Res., 171, 59-72, 2008.

Waichel, B. L., Lima, E. F. de, Viana, A. R., Scherer, C. M., Bueno, G. V., and Dutra, G.: Stratigraphy and volcanic facies architecture of the Torres Syncline, Southern Brazil, and its role in understanding the Paraná-Etendeka Continental Flood Basalt Province, J. Volcanol. Geoth. Res., 215-216, 74-82, 2012.

Williams, H. and McBirney, A. R.: Volcanoes, San Francisco, Freeman, Cooper and Company, 397 pp., 1979.

White, J. D. L., Mcphie, J., and Skilling, I. P.: Peperite: a useful genetic term, B. Volcanol., 62, 65-66, 2000. 